\title{
Use Of Online Communication Media "Google Classroom" In Lecture Activities During The Covid-19 Pandemic
}

\section{Penggunaan Media Komunikasi Daring “Google Classroom" Dalam Kegiatan Perkuliahan Selama Masa Pandemi Covid-19}

\author{
Meri Suarti ${ }^{1}$, Sri Narti ${ }^{2}$, Asnawati $^{3}$ \\ 1,2,3) Department of Communication, Faculty of Social Science, Universitas Dehasen \\ Bengkulu \\ Email: merisuarti@gmail.com
}

How to Cite :

Suarti, M; Narti, S; Asnawati, A (2021). Use Of Online Communication Media "Google Classroom" In Lecture Activities During The Covid-19 Pandemic. Sengkuni Journal: Social Sciences and Humanities Vol. 2 No. 12021 page: 27-44. DOI: https://doi.org/10.37638/sengkuni.2.1.27-44

\section{ARTICLE HISTORY \\ Received [23 April 2021] \\ Revised [03 May 2021] \\ Accepted [12 June 2021] \\ KEYWORDS \\ Online Communication, google classroom, relative advantage, compability, complexity, observability, triability, pandemi.}

This is an open access article under the $\underline{C C-B Y-S A}$ license

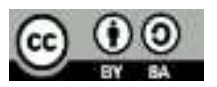

ABSTRAK

Tujuan penelitian ini untuk mengetahui penggunaan media komunikasi daring google classroom dalam kegiatan perkuliahan di Unived Bengkulu selama pandemic covid-29, penulis menggunakan karakteristik inovasi dari Everett $M$. Rogers yang mempunyai lima karakteristik yang dapat mempengaruhi tingkat penggunaan suatu inovasi, yaitu relative advantage, compatibility, complexity, triability, dan observability. Peneltian ini menggunakan metode deskriptif kualitatif dengan teknik pengumpulan data observasi, wawancara, dan dokumentasi. Teknik penentuan informan menggunakan purposive sampling, informan terdiri dari tiga orang dosen dan 9 orang mahasiswa. Hasil penelitian menyatakan bahwa berdasarkan karakteristik relative advantage, google classroom merupakan media yang fleksibel, simple dan efisien. Berdasarkan karakteristik compatibility, google classroom dirasakan sesuai untuk digunakan pada masa pandemic ini karena google classroom dapat diakses dimana saja dan dikapan saja yang terkoneksi dengan internet. Complexity dirasakan pada jaringan yang susah khususnya di pedesaan. Berdasarkan pengamatan selama uji coba disemester awal bahwa media ini dapat digunakan kembali pada semester berikutnya. Penggunaan media komunikasi daring google classroom dalam kegiatan perkuliahan selama pandemic covid-19 di Universitas Dehasen Bengkulu berjalan dengan lancar dan cocok untuk diterapkan pada masa covid-19, meskipun ada yang terkendala jaringan namun hal tersebut dapat diatasi karena memiliki tenggat waktu yang diberikan dosen

\section{ABSTRACT}

During the Covid-19 pandemic, lectures at Unived Bengkulu were conducted online. One of the media used to facilitate online communication during lectures is google classroom. Lecturing through google classroom is a new innovation for lecturers and students who 
previously lectured face to face and then conducted online. To find out
the use of online communication media, google classroom in lectures
at Unived Bengkulu during the Covid-19 pandemic, the author uses the
characteristics of innovation from Everett M. Rogers which has five
characteristics that can affect the level of use of an innovation, namely
relative advantage, compatibility, complexity, trialability, and
observability. This research uses descriptive qualitative methods with
data collection techniques of observation, interviews, and
documentation. The technique of determining informants using
purposive sampling, the informants consisted of three lecturers and
nine students. The results of the study state that based on the
characteristics of its relative advantage, google classroom is a flexible,
simple and efficient medium. Based on the characteristics of
compatibility, Google Classroom is considered suitable for use during
this pandemic, because Google Classroom can be accessed anywhere
and anytime that is connected to the internet. Complexity is felt in
difficult networks, especially in rural areas. Based on observations
during the trial in the early semester, this media can be reused in the
following semester. The use of online communication media google
classroom in lectures during the Covid-19 pandemic at Dehasen
Bengkulu University ran smoothly and was suitable to be applied
during the Covid-19 period, even though constraints with network, but
this could be overcome because it had a deadline given by the lecturer.

\section{PENDAHULUAN}

Upaya mencegah penyebaran Covid-19, pemerintah mengambil kebijakan untuk melaksanakan Social Distancing yaitu menghindari berkerumun, menghindari pertemuan massal dan menjaga jarak, salah satunya proses perkuliahan yang sebelumnya tatap muka (konvesional) dialihkan ke sistem perkuliahan dalam jaringan (daring).

Penerapan perkuliahan daring tentu saja tidak mudah untuk dilakukan karena mahasiswa memiliki tradisi dan terbiasa dengan perkuliahan secara konvesional. Perkuliahan daring ini disusun dengan scenario yang mampu untuk mencegah komunikasi secara langsung atau face to face antara dosen dan mahasiswa. Dalam hal ini diambil inisiatif bahwa perkuliahan dilakukan melalui media komunikasi daring.

Komunikasi secara daring merupakan berkomunikasi baik cara penerimaan maupun penyampaian pesan dilakukan melalui jaringan internet. Sementara media komunikasi daring merupakan media atau alat atau wadah yang dipergunakan dalam melakukan komunikasi melalui jaringan internet.

Perkembangan teknologi komunikasi saat ini semakin berkembang dan dimanfaatkan sebagai media komunikasi daring seperti Whatsapp, Google Classroom, Zoom, dll. Mahasiswa dan dosen sebagai adopter media komunikasi daring yang aktif tentu harus mengetahui bagaimana penggunaan media tersebut berdasarkan karakteristik inovasi.

Berdasarkan observasi awal penelitian menunjukkan bahwa media pembelajaran yang digunakan untuk kegiatan perkuliahan di Universitas Dehasen Bengkulu adalah whatsapp, classroom, zoom dan e-learning. Dari pengamatan peneliti media classroom digunakan pada setiap jurusan di Unived Bengkulu. Selain itu classroom memiliki fitur yang lebih menarik untuk diterapkan pada metode perkuliahan 
daring dibandingkan dengan media lainnya. Oleh karena itu peneliti memilih untuk meneliti media classroom.

Penerapan system perkuliahan di Universitas Dehasen Bengkulu berdasarkan Surat Edaran III Rektor Unived No. 0520/UNIVED/E-2/III/2020 tentang kebijakan UNIVED terkait dengan antisipasi penyebaran virus corona di lingkungan kampus. Dan Surat Edaran IV Rektor Unved No. 0535/UNIVED/E-2/III/2020 tentang tindak lanjut Surat Edaran III, bahwa perkuliahan dilakukan secara online atau daring.

\section{LANDASAN TEORI}

\section{Komunikasi Daring}

Menurut Wina, 2012:79, komunikasi merupakan suatu proses penyampaian pesan baik itu ide, gagasan dari sumber ke penerima pesan dengan maksud untuk memengaruhi penerima pesan. (Wina Sanjaya, 2012:79). Komunikasi bisa dikatakan efektif apabila ada feedback atau timbal balik dari penerima pesan baik itu berupa tanggapan, pertanyaan, jawaban, atau melaksanakan pesan yang disampaikan.

Komunikasi daring mengacu pada membaca, menulis dan berkomunikasi melalui/menggunakan jaringan internet. (Warschauer, M. 2001 pp. 207-212). Jadi dapat diartikan komunikasi daring adalah cara berkomunikasi dimana cara penyampaian dan penerimaan pesan dilakukan dengan atau melalui jaringan internet. Komunikasi daring terbagi menjadi Komunikasi Daring Sinkron dan Komunikasi Daring Asinkron.

Komunikasi daring sinkron menggunakan komputer sebagai media, yang terjadi secara bersamaan, real time. Contoh komunikasi daring sinkron adalah :

1. Pesan/chat Teks, merupakan aplikasi atau program di jaringan internet untuk berkomunikasi dan bersosialisasi secara langsung di antara pengguna internet yang sedang (online). Contoh Inbox Facebook, DM Instagram, Whatsapp, Telegram dan lainnya.

2. Video Call, sebuah aplikasi teknologi untuk berinteraksi secara audio dan video secara real time antara pengguna di lokasi yang berbeda. Video call biasanya dilakukan melalui perangkat komputer atau tablet/smartphone. Contoh VC Whatsapp, Zoom, Google Meet, dan lain sebagainya.

Komunikasi Daring Asinkron, ialah komunikasi yang menggunakan perangkat komputer yang dilakukan secara tertunda atau delay. Contoh komunikasi daring asinkron adalah :

1. E-mail

2. Google classroom

3. Forum

4. Membaca dan menulis dokumen secara online melalui world wide web.

Perkuliahan daring merupakan bentuk dari komunikasi dalam jaringan pada system pembelajaran yang cara penyampaian dan penerimaan pesan melalui internet baik secara sinkron maupun asinkron.

Fungsi komunikasi dalam jaringan diantaranya yaitu; (liputan6.com, 23 Jan 2019), untuk mendapatkan sebuah informasi.

\section{Media Komunikasi Daring}

Sri Narti mengatakan bahwa media komunikasi merupakan suatu alat yang dipergunakan untuk mempermudah rpenyampaian informasi dari seseorang kepada orang lain, untuk mencapai tujuan yang ditentukan (Sri Narti, 2016). Salah satu media komunikasi daring yang digunakan dalam perkuliahan daring di Universitas Dehasen Bengkulu adalah google classroom. 


\section{Google Classroom}

Berdasarkan Pada tahun 2018, Google mengumumkan penyegaran ruang kelas, menambahkan bagian pekerjaan kelas, meningkatkan antarmuka penilaian, memungkinkan penggunaan kembali pekerjaan kelas dari kelas lain, dan menambahkan fitur bagi guru untuk mengatur konten berdasarkan topik. Pada tahun 2019, Google memperkenalkan 78 tema bergambar baru dan opsi untuk menarik dan melepaskan topik dan tugas di bagian pekerjaan kelas.

Google Classroom bisa diakses dimana saja dan dimana saja yang terkoneksi dengan jaringan internet. Media yang digunakan bisa berupa PC atau smartphone. Untuk bisa masuk atau login ke google classroom dibutuhkan sebuah akun google. Google classroom dibagi menjadi dua mode yaitu untuk pengajar atau dosen dan untuk peserta didik atau mahasiswa.

\section{Difusi Inovasi}

Difusi inovasi memiliki dua unsur kata yaitu difusi dan inovasi. Rogers dalam bukunya Diffusion of innovations mendefinisikan "Diffusion is the process by which an innovation is communicatiated trough certain chanel over time among the member of a social system." (Difusi sebagai proses dimana suatu inovasi dikomunikasikan melalui saluran tertentu dalam jangka waktu tertentu diantara para anggota suatu sistem sosial). (Everett M Rogers, 2003:35). Teori difusi inovasi menjelaskan proses bagaimana suatu inovasi dikomunikasikan dan didistribusikan melalui saluran-saluran inovasi tertentu pada waktu tertentu kepada sekelompok anggota dari sistem sosial.

Rogers (2003:43) memberikan karakteristik-karakteristik inovasi yang mempengaruhi tingkat adopsinya yaitu:

1. Keuntungan relative (relative advantage)

Sejauh mana inovasi yang ditawarkan dianggap lebih baik dari pada ide terdahulu.. Semakin besar keuntungan relatif yang dirasakan dari sebuah inovasi, semakin cepat tingkat adopsi inovasi tersebut.

\section{Kesesuaian (compatibility)}

Sejauh mana inovasi dianggap sesuai dengan nilai-nilai yang ada, pengalaman masa lalu, dan kebutuhan calon pengadopsi. Ketidaksesuaian ide dengan nilai dan norma sistem sosial tidak akan diadopsi secepat inovasi yang kompatibel. Pengadopsian inovasi yang tidak cocok sering kali membutuhkan pengadopsian sebelumnya dari sistem nilai baru, yang merupakan proses yang relatif lambat.

\section{Kerumitan (complexity)}

Sejauh mana tingkat kesulitan inovasi untuk dipahami dan digunakan. Inovasi yang mudah dipahami oleh sebagian besar anggota sistem sosial akan lebih cepat diadopsi, sedangkan inovasi yang lebih rumit akan diadopsi lebih lambat.

4. Dapat di uji coba (triability)

Sejauh mana inovasi dapat diujicobakan secara terbatas. Ide-ide baru yang dapat diujicoba pada umumnya akan diadopsi lebih cepat daripada inovasi yang tidak dapat dibagi.

5. Dapat diamati (observability)

Semakin mudah bagi individu untuk melihat hasil inovasi, semakin besar kemungkinan mereka untuk mengadopsi. Visibilitas seperti itu mendorong diskusi 
sejawat tentang ide baru, karena teman dan tetangga pengguna sering meminta informasi evaluasi inovasi tentangnya.

Penelitian ini difokuskan pada bagaimana media komunikasi daring google classroom serta pembaharuannya dapat diterima ataupun ditolak oleh mahasiswa maupun dosen Unived Bengkulu. Seperti yang kita ketahui bahwa media komunikasi daring saat ini sangat beragam dan bervariasi dengan fiturnya masing-masing. Media komunikasi daring tersebut diterapkan pada sistem perkuliahan jarak jauh atau perkuliahan daring selama masa covid-19. Tentunya baik mahasiswa maupun dosen memiliki kebutuhan dan kepuasan tertentu terhadap media yang digunakan. Hal ini menjadi penting karena mempengaruhi efekifitas perkuliahan di Universitas Dehasen Bengkulu.

\section{METODE PENELITIAN}

\section{Jenis Penelitian}

Jenis penelitian yang digunakan adalah metode kualitatif yang mana prosedur penelitian yang menghasilkan data deskriptif berupa kata-kata tertulis atau lisan dari orang-orang dan perilaku yang dapat diamati.

Dalam penelitian ini peneliti berusaha mendeskripsikan hasil penelitian secara naratif. Teknik penentuan informan dilakukan dengan menggunakan teknik Purposive sampling yaitu teknik penentuan informan dengan kriteria dan pertimbangan tertentu, seperti orang tersebut yang dianggap paling tahu tentang apa yang kita harapkan. (Sugiyono, 2020:96). Pada penelitian ini informan diambil dengan kriteria berdasarkan pada orang-orang yang dianggap mampu untuk memberikan informasi secara lengkap dan berkaitan dengan penelitian sehingga data yang diperoleh dapat diakui kebenarannya. Dalam penelitian ini yang menjadi informan adalah dosen yang aktif menggunakan media google classroom sebagai media perkuliahan daring dan mahasiswa yang menerima perkuliahan dari dosen tersebut. Pada penelitian ini peneliti mengumpulkanan data dengan cara observasi, wawancara dan dokumentasi.

\section{Teknik Analisa Data}

Peneliti melakukan wawancara mendalam dengan informan yang benar-benar mengetahui dan memahami objek penelitian ini. Tentu saja wawancara tersebut direcord. Kemudian membuat transkrip hasil wawancara tersebut dengan cara mendengarkan kembali rekaman wawancara kemudian mencatat kata-kata yang tepat dengan penelitian ini. Setelah menulis transkrip hasil wawancara tersebut lalu peneliti membaca dengan cermat untuk kemudian dilakukan reduksi data dengan cara membuat abstraksi yaitu dengan mengambil dan mencatat informasi-informasi yang bermanfaat sesuai dengan konteks penelitian dan mengabaikan kata-kata yang tidak perlu sehingga didapatkan inti kalimat yang sesuai dengan bahasa informan. Abstraksi yang sudah dibuat dalam bentuk satuan-satuan yang kemudian dikelompokkan dengan berdasarkan taksonomi dari domain penelitian. 


\section{HASIL DAN PEMBAHASAN}

\section{Hasil Penelitian}

Pada masa pandemic ini sistem perkuliahan dilakukan secara daring. Mahasiswa dituntut untuk menerima system perkuliahan dengan menggunakan media komunikasi daring. Salah satu media yang digunakan dalam kegiatan perkuliahan selama pandemic covid-19 tersebut adalah "goole classroom". Google classroom merupakan media inovasi pembelajaran baru bagi dosen maupun mahasiswa, karena sebelumnya sistem pembelajaran dilakukan secara konvensional atau tatap muka kemudian dialihkan dengan menggunakan google classroom. Seperti yang dikatakan oleh informan NV:

"Classroom ini adalah kelas yang aktif lewat internet, jadi tidak lagi berupa kelas didalam ruangan secara nyata seperti yang biasa kita lakukan, classroom ini berupa kelas secara online dan tentu saja merupakan hal yang baru bagi saya dalam kegiatan perkuliahan" (wawancara, selasa, 26 Januari 2021)

Hal serupa juga dikatakan oleh informan RN:

"Media classroom ini merupakan media pembelajaran baru yang digunakan pada saat covid-19 ini karena kita tidak bisa melakukan tatap muka langsung, namun tidak mengurangi bagaimana kita menarik mahasiswa agar tetap aktif dalam perkuliahan" (wawancara, Kamis, 26 Februari 2021)

Menurut informan MF :

"Sebelum adanya pandemic, kami mahasiswa awam terhadap classroom, dan ini merupakan hal baru bagi kami” (wawancara, selasa, 27 Januari 2021

Begitu juga tanggapan dari informan lainnya, bahwa classroom adalah inovasi baru dalam sistem perkuliahan yang sebelumnya dilakukan secara tatap muka.

Pada penelitian ini, untuk mengetahui penggunaan media komunikasi daring "google classroom" dalam kegiatan perkuliahan selama pandemic covid-19 di Universitas Dehasen Bengkulu, peneliti menggunakan teori difusi inovasi dari Everett M. Rogers berdasarkan karakteristik inovasi yang mempengaruhi tingkat penerimaan inovasi tersebut. Karakteristik inovasi yang mempengaruhi tingkat adopsinya menurut Everett M. Rogers yaitu:

\section{Keuntungan Relatif (Relative Advantage)}

Keuntungan relatif melihat bagaimana suatu inovasi ini dapat dikatakan lebih baik dari inovasi sebelumnya atau justru tidak lebih baik dari inovasi sebelumnya. Pada penelitian ini yang menjadi tolak ukurnya adalah bagaimana informan merasakan langsung manfaat atau keuntungan yang dari penggunaan media google classroom yang menjadikanya puas ataupun tidak puas pada sebuah inovasi.

Berdasarkan hasil wawancara dengan informan RN bahwa google classroom dirasakan lebih fleksibel dibandingkan dengan media lain, dosen masih bisa memantau mahasiswa meskipun dimananpun mereka berada. Hal serupa juga disampaikan oleh informan NV, bahwa google classroom memiliki keuntungan pada tingkat fleksibelitas dalam kegiatan perkuliahan dimasa pandemic ini, google classroom ini tidak terikat pada waktu yang sangat ketat, misalnya jadwal hari senini jam 8 tidak harus ditentukan jam 8 seperti kuliah tatap muka, tapi mahasiswa dapat mengakses media ini kapan saja selama masih ada waktu tenggat yang diberikan. Menurut informan SE, bahwa dengan media ini bisa belajar dimana saja yang ada jaringan internet, hal ini juga disampaikan oleh NDL bahwa dengan media ini kuliah bisa sambil kerja. MF mengatakan bahwa google classroom memiliki keuntungan pada tingkat fleksibelitas dalam kegiatan perkuliahan 
dimasa pandemic ini. Informan MS juga mengatakan bahwa biasanya kalau kuliah dari dusun membutuhkan waktu berkisar 1 jam, namun karena menggunakan google classroom jadi lebih hemat waktu dan biaya perjalanan ke kampus.

Menurut hasil wawancara dari informan EL, bahwa google classroom efektif, memudahkan komunikasi antara dosen dan mahasiswa. Menurut IS bahawa media ini hemat tidak membutuhkan kuota atau data internet yang besar, serta tidak memerlukan ruang penyimpanan atau memori sehingga tidak perlu mengkhawatirkan memori hp yang penuh. Hal tersebut juga disampaikan oleh informan WM dan BK, ditambahkan oleh informan EL bahwa google classroom cukup efektif untuk digunakan dalam kegiatan perkuliahan karena dirasakan cukup simple dan pada umumnya mahasiswa sudah memiliki akun email sehingga memudahkan ketika menggunakan google classroom yang tersambung dengan email. Dosen atau mahasiswa hanya membutuhkan hp android dan jaringan yang stabil. Selain itu disampaikan oleh NSAA bahwa materi yang diberikan oleh dosen melalui google classroom ini tidak hilang akan tetap ada di akun google classroom kita.

Berdasarkan hasil wawancara dengan para informan dapat disimpulkan bahwa media classroom ini memiliki beberapa keuntungan yang menjadi pertimbangan bagi pengguna untuk memilih menggunakan media ini yaitu, fleksibel, simple, dan efisien (hemat). Hal ini selaras dengan hasil pengamatan penulis bahwa google classroom merupakan media yang hemat baik untuk penggunaan kuota data maupun untuk pemakaian ruang memori, selain itu media ini juga dapat diakses kapan saja dan dimana saja.

\section{Kesesuaian (Compability)}

Kesesuaian berkaitan dengan bagaimana suatu inovasi itu dapat dikatakan sesuai dengan kondisi masyarakat, kebudayaan dan nilai-nilai dalam masyarakat tersebut, serta tentu saja apakah sesuai dengan kebutuhan yang ada. Jika sesuai dengan apa yang disebutkan makan suatu inovasi itu akan mudah diadopsi bilamana tidak maka sebaliknya akan sulit diadopsi.

Tentu saja media classroom bisa dikatakan sesuai dengan system perkuliahan secara daring karena classroom menggunakan akses dengan internet dan tidak dengan tatap muka. Namun bukan hanya hal itu saja yang ingin diketahui dalam penelitian ini. Bahwa mahasiswa dituntut untuk menggunakan classroom sebagai media perkuliahan belum tentu cocok dengan tipikal mahasiswa pada umumnya yang lebih aktif jika kuliah tatap muka langsung.

Berdasarkan hasil penelitian dari karakteristik compability ini informan NV mengatakan google classroom ini sesuai untuk diterapkan dalam perkuliahan selama pandemic covid-19 ini, karena tidak memerlukan tatap muka secara langsung. Menurut informan EL bahwa media ini sesuai karena di dalam aplikasinya ada menu info, ada menu tugas, ada materi, kuis dan lainnya, sehingga sangat membantu dalam memberikan kuliah. Selain itu menurut NSAA bahwa media ini tidak terlalu banyak memakan kuota sehingga media ini dirasakan sesuai untuk digunakan dalam perkuliahan. Hal serupa ditambahkan oleh NDL, BK serta MF bahwa google classroom ini sesuai untuk kondisi saat ini. Kesesuaian juga dirasakan oleh informan AAS dan WM bahwa media ini lumayan cocok untuk saat ini namun untuk mata kuliah yang mengharuskan untuk praktek dirasakan kurang sesuai, sehingga materi yang disampaikan kurang maksimal, hal ini juga diutarakan oleh informan IS. 
Hal berbeda disampaikan oleh informan RN, bahwa sebenarnya untuk media pembelajaran kurang cocok karena tidak bisa tatap muka secara langsung dengan mahasiswa sehingga tidak bisa mengetahui apakah mereka benar-benar focus terhadap perkuliahan atau tidak. Hal serupa juga dikatakan oleh SE bahwa google classroom ini kurang cocok untuk perkuliahan karena dinilai ketika dosen memberikan materi kurang jelas dan sulit untuk dimengerti. Menurut informan MS bahwa google classroom ini kurang cocok karena tidak semua daerah mempunyai jaringan yang bagus.

Dari hasil wawancara diatas dapat dilihat bahwa dari 12 informan 9 menyatakan bahwa google classroom ini cocok, dan 3 informan menyatakan kurang sesuai. Berdasarkan dua pandangan ini dapat disimpulkan bahwa menurut pandangan dosen classroom ini sesuai dan telah memenuhi kebutuhan dosen dalam memberikan perkuliahan kepada mahasiswa. Sedangkan dari pandangan mahasiswa, classroom ini sesuai sebagai media penyampaian materi kuliah karena classroom hemat dengan penggunaan data, biaya dan ruang. Namun mahasiswa susah untuk memahami materi perkuliahan yang diberikan dosen. Selaras dengan hasil observasi penulis bahwa dengan google classroom ini mahasiswa banyak tidak mengerti dengan isi materi perkuliahan yang diberikan, karena kebanyakan mahasiswa tidak mau untuk belajar memahami sendiri materi tersebut.

\section{Kerumitan (Complexity)}

Kerumitan berkaitan dengan seberapa rumit suatu inovasi dapat dipahami dan dijalankan oleh adopter. Semakin rumit tentu saja akan semakin sulit untuk diadopsi begitu pula sebaliknya semakin mudah dipahami maka inovasi tersebut akan semakin mudah untuk diadopsi.

Melalui wawancara langsung dengan informan $\mathrm{RN}$ mengatakan bahwa google classroom cukup mudah untuk diaplikasikan, untuk mengetahui tentang penggunaan media ini bisa browsing di google sehingga tidak ada kesulitan dalam menjalankannya. Menurut NV tidak ada kendala atau kesulitan dalam menggunakan google classroom ini karena media ini cukup simple, sama seperti kelas hanya tidak tatap muka secara langsung. Hal ini dibenarkan oleh SE bahwa google classroom ini mudah digunakan karena memiliki fitur yang sederhana dan mudah dipahami, demikian menurut EL bahwa google classroom memiliki menu yang lengkap dan untuk mengaktifkannya cukup menggunakan akun gmail saja. Hal senada juga diungkapkan oleh NDL bahwa google classroom ini merupakan media belajar yang gampang digunakan karena tidak terlalu banyak icon-icon yang sulit dimengerti.

Selain itu, hasil penelitian mendapatkan bahwa memang terdapat kesulitan atau kerumitan kecil pada google classroom ini. Seperti yang diungkapkan oleh AAS bahwa ketika baru menggunakan google classroom memang terasa sulit. Kendala terdapat pada notifikasi google classroom yang sering terlambat masuk, sehingga telat mendapatkan pemberitahuan bahwa ada kuliah di google classroom. selain itu menurut IS bahwa materi yang di upload ke google classroom sulit dipahami karena tidak ada penjelasan secara langsung dari dosen. Sedangkan menurut MF mengalami kesulitan karena kurangnya sosialisasi sehingga membuat mahasiswa menjadi kebingungan saat mengumpulkan tugas, namun hal ini dirasakan pada awal menggunakan google classroom saja, namun seiring berjalannya waktu mahasiswa bisa lebih mengerti dan memahami penggunaan google classroom ini. seperti halnya yang diungkapkan oleh WM bahwa pada awalnya memang cukup sulit tapi setelah didalami menjadi lebih mudah, sedikit rumit hanya ketika ingin mendownload materi. MS mengatakan pada 
awalnya cukup sulit dan harus bolak-balik dengan fitur google classroom untuk mempelajari penggunaannya. Sedangkan menurut BK hanya terkendala pada jaringan yang jelek sehingga susah untuk masuk ke google classroom, namun hal ini bisa diatasi dengan mencari tempat yang memiliki jaringan yang bagus.

Dari hasil wawancara diatas pada awal menggunakan classroom informan merasa kesulitan, namun karena belajar bagaimana cara menggunakannya bisa browsing di internet maka informan bisa menggunakan google classroom dengan mudah. Kesulitan lain dapat ditemui pada jaringan terutama dari daerah yang susah sinyal, namun kesulitan ini bisa diatasi karena google classroom memiliki tenggat waktu pengerjaannya dan memberikan inisiatif kepada mahasiswa untuk mencari tempat yang jaringan internetnya bagus.

Dapat diuji coba (Triability)

Suatu inovasi akan lebih mudah diadopsi manakala inovasi tersebut dapat di uji cobakan dalam kondisi sebenarnya. Bahwa suatu inovasi tersebut sesuai atau tidaknya dapat segera diketahui manakala dapat dilihat melalui suatu uji coba. Dengan uji coba para adopter dapat mengetahui kelebihan dan kekurangan dari inovasi tersebut sebelum diadopsi seluruhnya.

Hasil penelitian dilapangan menemukan bahwa penggunaan google classroom dalam kegiatan perkuliahan di Universitas Dehasen Bengkulu tidak ada uji coba atau tutorial cara penggunaan media tersebut. Seperti yang disampaikan oleh RN bahwa waktu pertama kali mengetahui google classroom tidak ada uji coba atau petunjuk terlebih dahulu dari dosen atau rekan lainnya di kampus. Namun pengguna dengan berinisiatif untuk mencari tahu dan belajar sendiri bagaimana cara menggunakan media ini.

Hal senada diungkapkan oleh NV bahwa tidak ada uji coba atau toturial dari kampus, dengan belajar sendiri dan mencari tahu bagaimana cara menggunakannya dengan searching di google, ternyata cukup mudah dijalankan seperti halnya yang disampaikan oleh AAS dan BK bahwa mereka mencari tahu toturialnya di internet, dan bisa dipelajari dengan sendirinya. Hal ini juga disampaikan oleh NSAA bahwa tidak ada uji coba terlebih dahulu saat menggunakan google classroom, dengan seiringnya waktu bisa mengerti dengan sendirinya bagaimana cara menggunakan google classroom. Pernyataan ini juga disampikan oleh SE. Seperti yang disampaikan oleh NDL bahwa mereka belajar secara otodidak sendiri terkait dengan penggunaan google classroom. MF mengatakan bahwa kelasnya tidak mendapatkan tutorial atau petunjuk terkait bagaimana cara menggunakan google classroom melainkan mencari sendiri cara penggunaannya.

Informan EL mengatakan bahwa pertama kali mengetahui google classroom ini dari teman sesama dosen, memang tidak ada uji coba atau toturial terlebih dari pihak kampus. Setelah dipelajari dengan sendirinya ternyata penggunaanya cukup mudah dipahami. Menurut IS sering mendengar google classroom yang terdaftar dari email dari pihak lain, dan mengetahui google classroom ini dari teman dan mencari tahu sendiri di youtube bagaimana cara menjalankan aplikasi ini. Hal ini juga disampaikan oleh informan WM. Sementara menurut MS pertama kali dosen memerintahkan untuk download google classroom, kemudian belajar dengan sendirinya bagaiman fungsi dari menu-menu yang terdapat pada google classroom. namun karena tanpa didampingi oleh orang yang kompeten, mahasiswa masih meraba-raba dan masih bingung untuk

Berdasarkan hasil wawancara diatas dapat disimpulkan bahwa tidak ada uji coba terlebih dahulu dari pihak kampus. Baik dosen maupun mahasiswa belajar sendiri dan mencari 
tahu sendiri mengenai cara menggunakan classroom ini dengan mencari di internet terkait cara penggunaan classroom. Tetapi meskipun demikian, masih ada mahasiswa yang kurang mengerti tentang bagaimana cara menggunakan classroom.

\section{Dapat diamati (Observability)}

Observability merupakan tingkat dimana hasil-hasil inovasi dapat dilihat oleh orang lain. Semakin mudah seseorang melihat hasil dari penggunaan suatu inovasi, semakin besar kemungkinan individu tersebut untuk mengadopsinya, karena pengamatan tersebut dapat mengurangi ketidakpastian.

Penggunaan google classroom di Unived sendiri telah berlangsung beberapa semester. Pada semester awal pengguna google classroom dapat mengamati bagaimana penggunaan media ini. Hal ini dapat dijadikan evaluasi dan mempengaruhi sistem perkuliahan pada semester selanjutnya, apakah google classroom ini masih bisa digunakan atau tidak.

Terlihat pada hasil wawancara peneliti dan berdasarkan pengamatan dari informan EL bahwa google classroom cukup efektif untuk digunakan dalam perkuliahan, dosen bisa mengirimkan materi berupa video, modul tau berupa buku atau makalah. Sehingga dengan adanya media ini bisa mewakilkan dosen dalam pembelajaran online, oleh karena itu tentu saja goolge classroom bisa di terapkan dalam perkuliahan selama pandemic ini karena cukup mudah dan efektif untuk digunakan. Hal tersebut juga disampaikan oleh WM bahwa dari pengamatannya dibandingkan dengan media lain, goolge classroom cukup efektif karena tidak membuat memori hp menjadi kepenuhan. Begitu juga menurut SE bahwa media ini cukup efektif dan bisa diterapkan selama perkuliahan daring. Ditambahkan oleh BK bahwa google classroom ini cukup efektif hanya saja membuat mahasiswa menjadi sedikit malas karena kurang aktif.

Sementara dari hasil wawancara ada beberapa menurut informan google classroom dirasakan kurang efektif. Seperti berdasarkan pengamatan RN bahwa google classroom kurang efektif karena tidak bisa memantau secara langsung mahasiswa apakah benarbenar siap atau tidak dalam perkuliahan. Kalau untuk masa pandemic google classroom ini bisa diterima, tetapi memang lebih efektif dengan bertatap muka secara langsung. Jika dilihat selama ini, mahasiswa seringkali terlambat absen atau terlambat mengumpulkan tugas. Selain itu untuk mata kuliah praktek dosen harus memberikan video tutorial tentang materi mata kuliah tersebut dan dishare ke google classroom. Kurang efektifnya media ini juga dirasakan oleh informan NV. Jika membandingkan dengan perkuliahan tatap muka jelas google classroom kurang efektif, tetapi jika disbanding media perkuliahan daring lainnya google classroom lebih efektif dan lebih efisien. Selama ini google classroom dapat diterima dengan baik oleh mahasiswa meskipun ada beberapa mahasiswa yang mungkin desanya susah sinyal jadi jarang aktif atau jarang mengikuti google classroom. Sementara menurut AAG google classroom harus dipadukan dengan media lain karena salah satu kekurangan google classroom adalah tidak bisa melakukan video conference, jadi harus diselingi dengan media lain. Pada dasar google classroom hanya menerima materi dari dosen berupa tulisan atau video tanpa berinteraksi secara langsung dengan dosen.

Mahasiswa dituntut untuk membaca saja sehingga sulit mendapatkan ilmu dari mata kuliah tersebut. Hal senada juga diungkapkan oleh NDL bahwa penyampaian materi di google classroom dirasakan kurang, karena tidak ada diskusi atau timbal balik secara langsung dari dosen apakah mahasiswa telah memahami materi tersebut atau belum. 
Sementara menurut MF, dengan adanya google classroom ini mahasiswa suka menteledorkan waktu, sengaja mengulurkan waktu seperti yang diamatinya selama menggunakan google classroom. Tetapi penggunaan google classroom selama pandemic dinilai sudah sesuai karena kuliah tidak tatap muka, namun jika tidak ada pandemic dan tidak ada social distancing maka media ini tidak cocok karena banyak faktor yang merugikan mahasiswa. Hal ini juga disampaikan oleh MS bahwa google classroom ini kurang efektif untuk digunakan sebagai media perkuliahan, karena membuat mahasiswa menjadi pasif, hanya upload, download atau membaca saja. Padahal ada mahasiswa yang tidak paham dengan materi kuliah tersebut, sehingga mahasiswa merasa kurang puas dengan isi atau menu media tersebut.

Penggunaan classroom ini sudah dirasakan sendiri oleh dosen maupun mahasiswa di Universitas Dehasen Bengkulu. Pada masa pandemic ini classroom dirasakan bermanfaat sebagai media perkuliahan, hanya pada saat pandemic ini saja yang mengharuskan untuk melakukan komunikasi secara daring. Namun google classroom ini kurang efektif karena membuat mahasiswa menjadi pasif, dosen hanya membagikan materi atau tugas, tanpa ada penjelasan detail mengenai materi itu secara langsung. Pada umumnya mahasiswa malas untuk membaca dan belajar sendiri, dan sebaliknya mahasiswa pada umumnya membutuhkan penjelasan secara langsung, mendengar dan memahami materi secara langsung dari dosen.

\section{Pembahasan}

Berdasarkan temuan dilapangan bahwa google classroom ini memiliki 2 cara akses yang berbeda. Pertama yaitu google classroom melalui email/gmail yang mana notifikasi muncul di email dan bisa diakses melalui pesan masuk di gmail tersebut. Cara yang kedua yaitu melalui aplikasi google classroom yang bisa di download di play store dan diinstal di ponsel masing-masing, sehingga ketika ada kelas maka bisa diakses langsung melalui google classroom tersebut seperti halnya aplikasi wharsapp, tanpa harus masuk ke gmail terlebih dahulu.

Berdasarkan hasil penelitian yang telah diperoleh dilapangan maka dapat dibahas sebagai berikut:

\section{Keuntungan Relative (Relative Advantage)}

1. Google Classroom lebih fleksibel

Perkuliahan dapat dilakukan kapan saja dan dimana saja. Waktu perkuliahan tidak harus mengikuti jadwal seperti biasa, karena pada google classroom ini dosen memberikan waktu untuk pengerjaan yang cukup. Biasanya dosen memberikan over due atau jatuh tempo pengerjaan tugas maupun absensi yang cukup panjang sehingga memungkin semua mahasiswa memiliki kesempatan untuk mengikuti perkuliahan. Dengan adanya over due ini mahasiswa memiliki waktu dan persiapan untuk mengikuti perkuliahan. Seperti misalnya, bagi mahasiswa yang di daerah yang kurang sinyal, mereka bisa mencari tempat yang memiliki sinyal yang bagus untuk mengakses google classroom, seperti tempat yang lebih tinggi. Media ini bisa diakses dimana saja yang memiliki koneksi dengan internet. Meskipun mahasiswa mengalami koneksi yang buruk, tetapi perkuliahan tetap bisa diikuti karena ada limit waktu yang diberikan dosen, jadi setidaknya mahasiswa bisa berinisiatif dan mencari solusi bagaimana agar bisa mengakses google classroom ini.

2. Aplikasinya simple dan sederhana 
Google Classroom dapat dikatakan aplikasi yang sederhana yang bisa dipahami sendiri oleh penggunanya sehingga dosen maupun mahasiswa mampu mengaplikasikan google classroom ini dengan mudah. Meskipun ada beberapa pengguna yang mengalami kesulitan pada pertamakali menggunakan classroom ini, namun setelah dijalani akan terasa simple dan fitur-fitur yang dimiliki oleh cukup sederhana dan mudah dimengerti.

3. Hemat data dan hemat memori penyimpanan.

Salah satu keuntungan classroom ini adalah hemat, baik penggunaan data maupun penggunaan ruang penyimpanan. Tidak seperti media yang lain yang membutuhkan banyak kuota untuk bisa mengakses aplikasinya. Terlebih lagi sekarang dosen dan mahasiswa telah mendapatkan bantuan kuota dari pemerintah. Selain itu juga classroom ini tidak membutuhkan ruang penyimpanan di handphone karena materi yang dibagi ke classroom ini tersimpan langsung di google drive dan tidak memenuhi memori hp seperti halnya whatsapp, kecuali jika pengguna sengaja mendownload materi tersebut.

4. Memiliki fitur yang lengkap.

Classroom memiliki fitur yang lengkap, ada menu untuk sharing yang bisa digunakan untuk berbagi apa saja dalam forum yang bisa dilihat oleh semua anggota kelas, ada menu untuk tugas yang digunakan untuk melihat materi, tugas atau absen yang diupload oleh dosen dan terdapat kolom komentar yang bisa oleh publik ataupun privat, ada menu untuk absensi, dll. Bagi dosen, classroom ini sangat mewakili dalam perkuliahan. Dosen bisa membagikan materi ke google classroom bisa berupa tulisan, buku, makalah bahkan bisa membagikan materi dalam bentuk video.

\section{Kesesuaian (Compability)}

Pada sistem perkuliahan daring ini dipandang perlu untuk menggunakan media komunikasi atau media pembelajaran yang sesuai dengan nila-nilai dan kondisi saat ini. Masa pandemic saat ini mempengaruhi pada situasi sosial masyarakat. Pandemic covid19 ini berdampak pada berbagai sektor kehidupan masyarakat, baik dari segi ekonomi, lingkungan, bahkan pola hidup pada saat ini.

Perekonomian saat ini menurun drastis yang dialami seluruh lapisan masyarakat, salah satu faktor penyebabnya adalah karena adanya kebijakan untuk tetap dirumah, tidak diizinkan keluar rumah sehingga berpengaruh pada tatanan perekonomian. Banyak perusahaan yang berhenti beroperasi, banyak pekerja yang dirumahkan, petani yang tidak bisa mengolah kebun atau sawah, mereka, dll, sehingga masyarakat lebih berhatihati dalam mengelola keuangan, hal ini berdampak juga pada mahasiswa agar bisa mengatur keuangan sebaik mungkin.

Penggunaan google classroom sebagai media perkuliahan dirasakan sesuai dengan perekonomian karena google classroom merupakan aplikasi yang menggunakan data atau kouta yang tidak terlalu besar dan didukung dengan adanya bantuan kuota gratis dari pemerintah bagi dosen dan mahasiswa. Selain itu mahasiswa tidak membutuhkan ongkos atau uang bensin untuk ke kampus karena perkuliahan dapat dilakukan dari rumah.

Selain perekonomian, pandemic ini juga berdampak pada lingkungan dan pola hidup masyarakat saat ini, terutama pada mahasiswa. Jika sebelum pandemic perkuliahan dilaksanakan secara tatap muka, mengharuskan mahasiswa untuk disiplin waktu, bangun pagi dan bersiap untuk kuliah. Namun saat perkuliahan daring ini 
mahasiswa menjadi banyak menghabiskan waktu dengan percuma, bangun siang dan tidak memiliki disiplin waktu lagi.

Saat ini lingkungan masyarakat banyak berhubungan dengan dunia internet dan berkurangnya kontak atau interaksi langsung karena untuk menghindari penyebaran covid-19. Jika dilihat dari kesesuaian dengan lingkungan saat ini, google classroom dapat dikatakan telah sesuai dengan lingkungan selama masa pandemic ini yaitu perkuliahan dilakukan secara daring atau online dengan menggunakan media google classroom tanpa bertemu atau tatap muka secara langsung.

Berdasarkan dari wawancara di lapangan, terdapat 2 persepsi mengenai kompabilitas dari google classroom yaitu sesuai dan tidak sesuai. Menurut dosen, penggunaan media komunikasi daring google classroom ini tentu sesuai dengan perkuliahan secara daring saat ini karena memerlukan koneksi dengan internet untuk mengaksesnya, tidak perlu untuk bertatap muka secara langsung. Google classroom memudahkan dosen dalam memberikan perkuliahan kepada mahasiswa.

Sedangkan menurut mahasiswa, penggunaan google classroom sesuai hanya sebagai media pembelajaran secara daring pada masa pandemic ini saja, namun dirasakan kurang sesuai bagi sebagian mahasiswa yang biasanya tergolong aktif berinteraksi di dalam kelas, seperti aktif bertanya kepada dosen atau berperan aktif ketika berdiskusi dan presentasi di kelas. Menurut pengamatan peneliti bahwa mahasiswa biasanya memiliki karakter yang berpikir kritis, kreatif, pintar berkomunikasi, percaya diri, peduli serta mudah beradaptasi. Namun dengan adanya perkuliahan daring menggunakan google classroom ini mahasiswa tidak bisa mengexplore semua itu. Melalui google classroom ini mahasiswa tidak bisa menunjukkan eksistensi diri mereka di dalam kelas, karena komunikasi secara langsung dirasakan sangat berbeda dengan komunikasi melalui media. Jika komunikasi secara langsung mahasiswa akan mendapatkan kepuasan tersendiri atas kemampuan interaksi mereka.

Mahasiswa memiliki dua tipe yang mempengaruhi cara mereka menerima perkuliahan. Pertama adalah mahasiswa yang benar-benar kuliah untuk menuntut ilmu, untuk mendapatkan keahlian dan meningkatkan kemampuan dibidangnya. Tipe mahasiswa ini biasanya benar-benar belajar dan mengikuti perkuliahan dengan baik. Google classroom ini akan dirasakan kurang sesuai oleh mahasiswa pada tipe ini, karena media ini kurang pembahasan pada materi perkuliahan yang diberikan, terutama pada matakuliah praktek, media ini tidak dapat diterapkan. Ketika dosen memberikan perkuliahan melalui classroom, dosen hanya mengupload materi, memberikan tugas atau memberikan video saja tanpa ada penjelasan seperti kuliah tatap muka. Mahasiswa merasa tidak ada bekal ilmu yang didapat dalam perkuliahan dengan classroom ini, karena pada dasarnya mahasiswa sulit hanya dengan membaca saja, tetapi mahasiswa membutuhkan interaksi secara langsung agar perkuliahan berjalan efektif dan ada timbal balik antara dosen dan mahasiswa. Tipe yang kedua adalah mahasiswa yang hanya sekedar kuliah untuk mendapatkan nilai dan gelar sarjana saja. Pada tipe ini mahasiswa tidak perduli dengan metode apa yang digunakan untuk perkuliahan. Hal terpenting bagi mahasiswa ini adalah dosen memberikan nilai yang baik.

\section{Kerumitan (Complexity)}

Pada awalnya memang pengguna mengalami kesulitan dalam menggunakan classroom ini. Fungsi menu yang terdapat pada classroom ini tergolong rumit, namun semakin menjalani, maka semakin mengerti. Selain fungsi pada menu, terdapat kerumitan pada waktu pengumpulan tugas. 
Kesulitan yang sering ditemukan pada penggunaan classroom ini adalah jaringan yang tidak stabil, terutama bagi yang tinggal di pedesaan Agar bisa masuk ke classroom mereka harus mencari dataran tinggi atau daerah yang terkoneksi dengan internet. Bagi yang sinyalnya jelek, maka mereka tidak bisa membuka tugas di classroom, bahkan membuka video yang dishare oleh dosen. Selain itu tidak bisa melakukan panggilan video atau video conference.

Selain itu juga tidak ada pemberitahuan atau notifikasi kepada pengguna, sehingga mahasiswa sering mengalami keterlambatan informasi mengenai materi, absen atau tugas yang dishare ke google classroom. Berdasarkan pengamatan penulis hal ini sering terjadi pada pengguna google classroom melalui akun email, karena notifikasi email sering terlambat masuk disebabkan oleh jaringan, atau bahkan notifikasi email atau google classroom tidak diaktifkan sehingga tidak mendapatkan pemberitahuan terkait adanya perkuliahan.

\section{Dapat Diuji Coba (Triability)}

Google classroom merupakan media yang populer di dunia pendidikan dan google classroom merupakan media inovasi baru dalam kegiatan perkuliahan atau pembelajaran. Google classroom bukan sebuah inovasi yang bisa diujicoba dalam waktu singkat seperti inovasi pada kebutuhan peralatan. Namun google classroom membutuhkan waktu yang lama untuk uji coba, misalnya google classroom digunakan pada satu semester untuk dilakukan uji coba, dan bisa di evaluasi bagaimana tingkat penggunaan pada google classroom ini, apakah layak digunakan pada semester berikutnya atau tidak.

Berdasarkan hasil penelitian dilapangan bahwa google classroom ini pada awal penggunaannya tidak ada petunjuk atau tutorial terlebih dahulu dari pihak kampus, namun pengguna google classroom baik dosen maupun mahasiswa dengan otodidak berinisiatif untuk belajar sendiri bagaimana cara menggunakan google classroom. Selain itu juga di internet atau di youtube terdapat tutorial mengenai cara penggunaan google classroom ini sehingga memudahkan penggunanya untuk belajar.

Jika dilihat dari hasil wawancara, penggunaan google classroom dirasakan simple atau mudah untuk digunakan. Setelah uji coba selama satu semester menggunakan google classroom dosen merasakan penggunaan google classroom yang mudah untuk diterapkan dan menu yang dimiliki google classroom lebih lengkap dan fleksibel, maka dosen di Universitas Dehasen Bengkulu memilih media google classroom sebagai media pembelajaran dalam kegiatan perkuliahan selama pandemic covid-19.

\section{Dapat Diamati (Observability)}

Penulis menemukan hal yang menarik dari hasil wawancara dilapangan bahwa dosen merasa google classroom ini tepat untuk digunakan sebagai media perkuliahan, namun ada sebagian menurut mahasiswa merasa bahwa google classroom ini tidak cocok untuk digunakan sebagai media pembelajaran. Dari hasil wawancara dengan informan mahasiswa bahwa mereka mempunyai pengalaman yang tidak mengenakan selama perkuliahan dengan menggunakan google classroom. Ketika dosen memberikan tugas dalam bentuk video, waktu mengirimkan video tersebut susah dan lama sekali untuk menguploadnya. Bahkan ada video tersebut sampai tidak terkirim. Hal ini mungkin karena pengaruh jaringan. Ketika uas menggunakan google classroom, dosen memerintahkan untuk membuat makalah dan dikirim ke google classroom. Mahasiswa 
tersebut mengira bahwa tugas sudah terkirim ternyata belum, sehingga mahasiswa tersebut mendapatkan nilai yang kurang memuaskan.

Kendala yang dimiliki oleh mahasiswa selama menggunakan google classroom ini seringkali terjadi pada jaringan, terutama pada mahasiswa yang dari desa. Terkadang sinyal tergantung pada lampu/listrik. Ketika mati lampu sinyalnya mati dan mereka tidak bisa mengakses google classroom.

Selama melakukan pengamatan pada google classroom ini, ternyata memiliki efek yang kurang baik bagi mahasiswa. Hal ini dapat dilihat dari tindakan mahasiswa yang sengaja molor waktu karena mereka tahu bahwa di google classroom akan ada tenggang waktu yang diberikan oleh dosen, sehingga mahasiswa bisa bermalas-malasan untuk mengerjakan tugas atau mengisi absen. Berbeda dengan zoom yang video secara langsung, jika tidak ikut zoom pada waktu yang ditentukan maka absen dianggap tidak hadir. Namun dengan google classroom bisa "nanti saja", tetapi hal itu bukan permasalahan bagi dosen, yang terpenting adalah mahasiswa tidak melewati tenggat waktu yang diberikan.

\section{Kesimpulan}

\section{KESIMPULAN DAN SARAN}

1. Keuntungan Relative (Relative Advantage) yaitu, Google classroom media yang fleksibel, memberikan kemudahan dalam efisiensi biaya karena tidak membutuhkan banyak kuota, hemat pada ruang dan waktu, google classroom bisa diakses dimanapun yang terkoneksi internet, kapanpun dan tidak membutuhkan ruang penyimpanan atau memori di hp. Google classroom merupakan media yang sederhana, pengoperasianya mudah. Keuntungan ini dapat dirasakan baik oleh dosen maupun mahasiswa.

2. Kesesuaian (Compability) yakni, dapat dilihat dari pendapat dari dosen bahwa google classroom sudah sesuai untuk kondisi pandemic saat ini yang mengharuskan agar perkuliahan dilakukan secara daring. Namun tidak semua mahasiswa merasa sesuai dikarenakan dirasakan kurang mendapatkan ilmu dari dosen sehingga merasa bahwa belajar melalui googel classroom hanya sebuah formalitas perkuliahan saja, mereka lebih tertarik untuk melalukan perkuliahan tatap muka.

3. Kerumitan (Complexity) yaitu, pada awal menggunakan google classroom, baik dosen maupun mahasiswa mengalami kesulitan bagaimana cara menjalankan aplikasi ini. Namun setelah diamati dan dipelajari ternyata google classroom tergolong mudah untuk digunakan. Tetapi setiap mahasiswa memiliki kemampuan yang berbeda, oleh karena itu masih ada mahasiswa yang belum mengerti bagaimana menjalankan google classroom. Hal yang menjadi kendala adalah terletak pada jaringan, terutama bagi mahasiswa dari daerah.

4. Dapat diuji coba (Trialability) yaitu, digunakan selama satu semester awal untuk uji coba dan dirasakan bahwa media ini cukup layak untuk digunakan dalam kegiatan perkuliahan selama pandemic covid-19 maka semester selanjutnya ditetapkan menggunakan google classroom sebagai media pembelajaran. Waktu pertama kali menggunakan google classroom tidak ada petunjuk atau tutorial dari pihak kampus maupun dosen, namun karena media ini merupakan media pembelajaran yang populer sehingga tutorial cara penggunaannya tersedia di youtube,dan pengguna bisa mempelajari sendiri melalui tutorial tersebut. 
5. Dapat diamati (Observabilty) yakni, pada awal penggunaan media ini dapat diamati dan dirasakan bahwa media ini bagus untuk digunakan dalam perkuliahan dan tidak ada keluhan dari pengguna google classroom baik dosen maupun mahasiswa sama-sama telah belajar dari semsester sebelumnya dan dapat memperbaiki kekurangan yang pernah dialami di semester sebelumnya.

Jadi kesimpulannya, penggunaan media komunikasi daring google classroom dalam kegiatan perkuliahan selama masa pandemic covid-19 di Universitas Dehasen Bengkulu berjalan dengan lancar dan cocok untuk diterapkan pada masa covid-19, meskipun ada beberapa mahasiswa dari daerah yang terkendala pada jaringan sehingga perkuliahan dengan google classroom ini dirasakan kurang efektif namun hal itu bisa diatasi karena google classroom memiliki tenggat waktu perkuliahan yang bisa dimanfaatkan mahasiswa untuk tetap bisa mengikuti perkuliahan dan mengerjakan tugas sesuai dengan due date yang sudah ditentukan oleh dosen.

\section{Saran}

1. Sebaiknya dari pihak kampus atau dosen mengadakan pelatihan terlebih dahulu tentang cara menggunakan google classroom, atau tempat dimana tugas harus diupload sebelum perkuliahan dimulai

2. Sebaiknya dosen memberikan informasi terlebih dahulu kepada mahasiswa atau komti sebagai perwakilan kelas bahwa ada perkuliahan di google classroom agar perkuliahan berjalan dengan baik dan seluruh anggota kelas dapat mengikuti perkuliahan, karena terkadang mahasiswa tidak menerima notifikasi dari google classroom sehingga mahasiswa telat mengikuti perkuliahan.

3. Sebaiknya dosen mengadakan kesepakatan atau kontrak belajar terlebih dahulu dengan mahasiswa diawal perkuliahan mengenai media yang akan digunakan dan cara akses yang ingin digunakan apakah dengan email atau download aplikasi google classroom. Penulis lebih menyarankan agar menggunakan cara akses yang kedua yaitu melalui aplikasi google classroom langsung, karena dengan aplikasi yang sudah diinstal di ponsel ini jika ada kelas maka notifikasinya langsung muncul dan tidak tertunda.

4. Agar perkuliahan dapat bermanfaat dan mahasiswa bisa mengerti tentang mata kuliah yang diberikan maka sebaiknya dosen menjelaskan terlebih dahulu mengenai materi kuliah tersebut, bukan hanya memberikan materi sekian halaman kemudian mahasiswa diperintahkan untuk absen atau mengerjakan tugas, kemudian perkuliahan selesai. Jika demikian mahasiswa akan malas untuk belajar, karena mahasiswa pada umumnya malas untuk membaca dan memahami materi dengan mandiri.

5. Disarankan kepada mahasiswa untuk lebih kritis dan aktif menyampaikan pendapat mengenai media apa yang digunakan dalam kegiatan perkuliahan, sehingga manfaat perkuliahan bisa benar-benar dirasakan oleh mahasiswa. Sebaiknya mahasiswa tidak harus selalu menyetujui apa yang dosen tentukan, jika hal itu dirasakan kurang sesuai oleh mahasiswa, maka mahasiswa berhak untuk memberikan sanggahan dengan argument yang tepat. 


\section{DAFTAR PUSTAKA}

Arafat, Nida. 2019. Difusi Inovasi Penggunaan Aplikasi Dakwah. Skripsi Ilmu Dakwah dan IImu Komunikasi Universitas Islam Negeri Syarif Hidayatullah. Jakarta.

Cangara, Hafied. 2012. Pengantar Ilmu Komunikasi. Jakarta, Rajawali Pers.

Elisa P, Gartika. 2017. Difusi Inovasi Program Pajak E-filling. Skripsi Program Studi Ilmu Komunikasi Fakultas Komunikasi dan Informatika Universitas Muhammadiyah Surakarta.

Hanafi, Abdillah. 1987. Memasyarakatkan Ide-Ide Baru. Surabaya, Usaha Nasional.

Hilmi Z, Nabila, 2020. Persepsi Mahasiswa Terhadap Perkuliahan Daring Sebagai Sarana Pembelajaran Selama Masa Karantina (Covid-19). Jurnal Bisnis dan Kajian Strategi Manajemen. Universitas Teuku Umar. Volume 4 Nomor 1.

McQuail, Denis. 2005. McQuail's Mass Communication Theory. London, SAGE Publications.

Moloeng, Lexy. 2019. Metodologi Penelitian Kualitatif. Bandung, PT. Remaja Rosdarya

Mulyana, Deddy. 2008. Ilmu Komunikasi Suatu Pengantar. Bandung, Remaja Rosdakarya.

Narti, Sri, 2016. Pemanfaatan Whatsapp Sebagai Media Komunikasi Dosen Dengan Mahasiswa Bimbingan Skripsi. Jurnal Profesional FIS Unived Bengkulu. Volume 4 No. 1

Ni'mah, Ghaniyah. 2016. Penggunaan Internet Sebagai Media Komunikasi Dalam Meningkatkan Aktivitas Belajar Mahasiswa. IImu Komunikasi Fakultas IImu Sosial dan Humaniora Universitas Islam Negeri Sunan Kalijaga Yogyakarta

Rahardjo M, Daryanti. 2015. Teori Komunikasi. Yogyakarta, Gava Media.

Rogers, Everett. 2003. Difussion of Innovation. New York., Free Press

Sadikin, Ali dan Afreni. 2020. Pembelajaran Daring Ditengah Wabah Covid. Jurnal IImiah Pendidikan Biologi. Volume 6 Nomor 2.

Sanjaya, Wina. 2012. Strategi Pembelajaran Berorientasi Standart Proses Pendidikan. Jakarta: Kencana

Sanjaya, Wina. 2019. Media Komunikasi Pembelajaran. Jakarta, PT. Fajar Interpratama Mandiri.

Satiyasih R, Eli. 2020. Aktivitas Pembelajaran Daring Pada Masa Pandemic Covid-19 di Jurusan Pendidikan Geografi Jurnal Universitas Siliwangi, Tasikmalaya. Volume 1 Nomor 1

Sugiyono, 2020. Metode Penelitian Kualitatif. Bandung, CV. ALFABETA.

Syaipudin, Latif. 2020. Peran Komunikasi Massa di Tengah Pandemi Covid-19. Kalijaga Journal of Communication. Volume 2 Nomor 1.

Tankard J dan Severin W. 2011. Teori Komunikasi: Sejarah, Metode, dan Terapan di Dalam Media Massa. Jakarta, Kencana.

Wiadhiyana, Erica. 2020. Dampak covid-19 Terhadap Kegiatan Pembelajaran Online Disebuah Perguruan Tinggi Kristen di Indonesia. Jurnal Perspektif IImu Pendidikan. Volume 34 Nomor 1

https://en.m.wikipedia.org/wiki/covid-19pandemi (diakses tanggal 12/09/2020 21:40)

https://id.wikipedia.org/wiki/Media_daring (diakses tanggal 26/09/2020 16.25)

https://www.liputan6.com/citizen/read (diakses tanggal 25/09/2020 15:13) 
https://pddikti.kemdikbud.go.id/data_pt/798628C0-06B9-4490-8824-93C7FE716366 (diakses tanggal 23/02/2021) 